\title{
Biochemical and histopathological changes in male albino rats treated with overdose of an aqueous extract of pomegranate (Punica granatum L.) pericarps
}

\author{
Enas A. M. Khalil \\ National Organization For Drug Control And Research
}

\begin{abstract}
Pomegranate has been cultivated since ancient times. All parts of this plant were used to treat various ailments.

It mentioned for three times in the Holy Quran under the name of Rumman in Surah (AlAnaam) verse 99, Surah (Al-Anaam) verse 141 and Surah (Al-Rahman)verse 68.

In Surah (Al-Anaam) verse 141." It is He who produce the gardens with trellises and without ,and dates and tilth with produce of all kinds and olives and pomegranates, similar (in kind ) and different (in variety) :eat of their fruit in their season ,but the dues that are proper on the day that the harvest is gathered .But waste not by excess. For Allah loves not the wasters".

This investigation aims to study the effect of repeated over doses of an aqueous extract of pomegranate ( Punica granatum L .) pericarps in male albino rats for a month.

Oral administration of repeated over doses $(1.3 \mathrm{~g} / \mathrm{k})$ of an aqueous extract of pomegranate ( Punica granatum L .) pericarps in male albino rats for month displayed significant increase in serum aspartate aminotransferase (AST), alanin aminotransferase (ALT), alkaline phosphatase and liver revealed congestion of central vein, dilatation of sinusoids, vacuolization and (ALT) ballooning also a lot of pyknotic nuclei were detected with many necrotic areas of hepatocytes. Inflammatory cells were detected inbetween hepatocytes, dilatation of the portal tract and fibrosis noticed around it. Elevation of serum urea , creatinine, dilatation and severe congestion of blood vessels, most glomeruli were congested ,dilatated, and some appeared degenerated. Diffuse extravagations of red blood cells between the degenerated renal tubules were noticed .Augmentation of serum total cholesterol, decreased serum triglycerides and formation of medial calcinosis in aorta. Reduction in serum testosterone level, some seminiferous tubules appeared normal but the others appeared affected.

All things must be taken in moderation because repeated high doses of an aqueous extract of pomegranate pericarps will be toxic.
\end{abstract}

\section{Introduction}

Pomegranate (Punica granatum L.), belongs to punicaceae family. Flavonoidrich poly phenol fractions from pomegranate inducing chemicals with a potentially lower toxicology profile than other therapies. All parts of this plant were used to treat various ailments. The extract of root bark has been reported to exert some sugar lowering action in animals (Carraz, et al ,1978), the extract of stem bark is used as anthelmintic, green leaves are made as a paste and applied in conjunctivitis (Satyavati et al ,1978), flowers used as anthelmintic, (Singhal ,1983), as hypoglycaemic agent (Jafri et al, 2000), peels displayed ,haemostatic, antidiarrhoeal, antifertility (Duck et al, 2002), adjunctive periodontal (Sastravaha et al, 2003) ,as an antifungal agent against candidosis associated with denture stomatitis (Vasconcelos et al , 2003), as a strong therapy for leukemia cells (Kawaii and Lansky, 2004), seed extract showed antidiarrhoeal activity (Das et al, 1999), seed displayed hypoglycaemic activity (Das et al, 2001)and fruit extract possesses antioxidant activity (Noda et al, 2002), improves a depressive state and bone 


\section{Enas A. M. Khalil}

properties in menopausal syndrome model (Mori-Okamoto et al , 2004), reduced common carotid intimae-media thickness, blood pressure and LDL oxidation ( Aviram et al, 2004) and inhibit skin tumorigenesis in mice (Afaq et al, 2004).

In Surah (Al-Anaam) verse 141 God ordered us to eat pomegranate and forbidden to eat excess.

Vidal et al, 2003 recorded that LD50 of pomegranate extract determined in mice was $731 \mathrm{mg} / \mathrm{k}$ and they added that toxic effects of Punica granatum fruit extract occurred at higher doses than those effective in the models for the treatment of respiratory diseases in Cuban folk medicine.

All things must be taken in moderation.

This investigation aims to study the effect of repeated over doses of an aqueous extract of pomegranate ( Punica granatum L.) pericarps in male albino rats for month.

\section{Material and methods \\ Plant material}

$200 \mathrm{ml}$ boiling distilled water was added to5gm powder pomegranate peel, left it for 10 minutes and filtered.The filtrate was dried at 40-45C0 in the incubator .

\section{Animals}

14 adult male albino rats weighing $120-150 \mathrm{~g}$ were obtained from breeding in animal lab. histology department in NODCAR. The animals were housed under good hygienic condition, diet and water excess

\section{Experimental design}

The animals were divided into two groups. Group I, served as control consisted of six rats, group II consisted of 8 animals was given pomegranate aqueous extract $(1.3 \mathrm{~g} / \mathrm{k}$. p.o. $)$ in a dose 3 fold the therapeutic dose (Paget and Barnes, 1964)

\section{Blood sampling}

After 30 days from pomegranate aqueous extract administration, blood samples were collected from retro-orbital vein in the two groups. The blood was allowed to collect at room temperature and serum obtained after centrifugation was used for determination serum aspartate aminotransferase, alanine aminotransferase (Reitman and Frankle,1957) alkaline phosphtase ( German Society for clinical chemistry,1972) ,urea (Tabacco et al, 1979), creatinine (Bartles et al,1971) ,total cholesterol (Allain et al., 1974), Triglycerides (Bucolo and David,1973) testosterone was estimated by Kit obtained from IMX Abbott Labs, IL/USA.

Fresh liver, kidney, aorta samples were collected in formalin $10 \%$. Testes were collected in Bouin' fluid. All samples were stained with $\mathrm{H} \& \mathrm{E}$.

\section{Statistical analysis}

All data obtained were analyzed using student't'-test according to Sendecor and Coebram (1969).

\section{Results and Discussion}

Pomegranate juice contains, a wide of polyphenolic compounds including ellagic, gallic ,anthocyanins and tannins especially punicalagin, which is a power antioxidant ,pomegranate showed antioxidant activity three times higher than those of green tea (Schubert etal,1998).Green tea possessed hepatoprotective activity at the therapeutic dose (Peirce,1999), if one consumed the equivalent of $65 \mathrm{~g}$ tea leaves /day for 5 years would exhibit liver dysfunction, much astringent tannins, which can damage the liver and intestine with prolonged use (Pedersen,1998). Duck et al,2002 recommended that tannins should call (poly phenols )useful antioxidant good guys instead of hepatotoxic bad guys, so all things must be taken in moderation.

The Pomegranate rind contains tannins, anthocynins, flavonoids ,pectins (Nozire and Serpil, 1993), ellagitannins (punicalin, punicalagin, granatin, gallagyldilactone, casurinin,), pedunculagin, tellimagrandin ,corilagin (Satomi et al, 1993), ellagic tannins, gallic, ellagic acids , ursolic acid (Ben-Nasr et al,1996)and catechin (Chidambara et al, 2004) three estrogen 
compounds luteolin, quercetin and kaempferol (Van-Elswijk et al, 2004).

Pomegranate is known to contain estrogens (estradiol, estrone, estriol) and shows estrogenic activities in mice (MoriOkamoto et al ,2004).

It means that pomegranate rind extract contains poly phenolic compounds which behaves like estrogens (kummer et al, 2001) and also, it contains estrogens.

In this investigation, the repeated overdose administration of pomegranate extract pericarps for month in male albino rats led to significant increase in (AST), (ALT) , ALP(table 1) and liver revealed congestion of central vein, dilatation of sinusoids(fig.1), vacuolization and ballooning also a lot of pyknotic nuclei were detected with many necrotic areas of hepatocytes(fig.2). Inflammatory cells were detected inbetween hepatocytes (fig.2), dilatation of portal tract and fibrosis around it, dilated endothelium with the disappearance of their nuclei,debris of a lot of hepatocytes were observed (d), a large necrotic area could be detected(n) (figs4\&4a) compared with control(fig.1) this result was in accordance with conclusion of (Pedersen,1998) much tannins with prolonged use can damage the liver. Eleuation in serum urea and creatinine (table1) may be due to liver dysfunction (Lanter, 1975), and impairment in kidney glorwli and tubules concerning kidney structure dilatation and severe conges-tion of blood vessels, some nuclei of convoluted tubules appeared faintly stained and their cells appeared moderately affected, some glomeruli appeared lobulated and atrophied (fig.11), most glomeruli were congested, dilatated (figs6 \&7), some appeared degenerated (fig.9,11) and some appeared compact (figs. 6). Diffuse extravagations of red blood cells between the degenerated renal tubules were noticed (fig.10)compared to control (fig.5). Augmentation of serum total cholesterol, decreased serum triglycerides(table1) and formation of medial calcinosis in aorta with irregularity of tunica intima (figs.13,13a) compared to control (fig.11) Reduction in serum testosterone level (table1) attributed to regulation for testosterone synthesis may be affected by phytoestrogen rich diet and decreased testosterone levels (Weber et al, 2001) and or administration of high estrogens doses affect germ cells via a testosterone deficiency (Kaneto et al,1999), some seminiferous tubules appeared normal but the others contained less spermatogenic activity with reduction in sperm number and leyding cells(figs. $15 \& 15 \mathrm{a}$ ) compared to control (fig.14) .

All things must be taken in moderation because repeated high doses of an aqueous extract of pomegranate pericarps for month displayed toxic effects. 
Table(1): showing the effect of treatment with overdose $(1.3 \mathrm{~g} / \mathrm{kg})$ of an aqueous extract of pomegranate epricarps on some liver function tests, kidney function tests ,cholesterol ,triglycerides and testosterone for month in male albino rats.

\begin{tabular}{|c|c|c|}
\hline Parameters & control & Treated with overdose \\
\hline $\begin{array}{c}\text { AST } \\
(\mathrm{U} / \mathrm{L})\end{array}$ & $\begin{array}{l}38.7 \\
\pm 1.9\end{array}$ & $\begin{array}{c}46.33 \uparrow * \\
\pm 2.02\end{array}$ \\
\hline $\begin{array}{c}\text { ALT } \\
\text { (U/L) }\end{array}$ & $\begin{array}{c}22 \\
\pm 1.76\end{array}$ & $\begin{array}{l}28 \uparrow * \\
\pm 1.55\end{array}$ \\
\hline $\begin{array}{l}\text { ALP } \\
\text { (U/L) }\end{array}$ & $\begin{array}{c}83 \\
\pm 2.21\end{array}$ & $\begin{array}{l}94 \uparrow^{*} \\
\pm 3.07\end{array}$ \\
\hline $\begin{array}{l}\text { Urea } \\
\mathrm{mg} / \mathrm{dl}\end{array}$ & $\begin{array}{l}21.33 \\
\pm 1.31\end{array}$ & $\begin{array}{l}16.6 \downarrow^{*} \\
\pm 0.98\end{array}$ \\
\hline $\begin{array}{l}\text { Creatinine } \\
\mathrm{mg} / \mathrm{dl}\end{array}$ & $\begin{array}{c}0.8 \\
\pm 0.98\end{array}$ & $\begin{array}{l}0.35 \downarrow^{*} \\
\pm 0.17\end{array}$ \\
\hline $\begin{array}{c}\text { Cholesterol } \\
\mathrm{mg} / \mathrm{dl}\end{array}$ & $\begin{array}{c}130 \\
\pm 2.71\end{array}$ & $\begin{array}{c}145 \uparrow * * \\
\pm 4.12\end{array}$ \\
\hline $\begin{array}{c}\text { Triglycerides } \\
\mathrm{mg} / \mathrm{dl}\end{array}$ & $\begin{array}{c}56.4 \\
\pm 3.11\end{array}$ & $\begin{array}{l}46.47 \downarrow^{*} \\
\pm 2\end{array}$ \\
\hline $\begin{array}{c}\text { Testosterone } \\
\mathrm{ng} / \mathrm{ml}\end{array}$ & $\begin{array}{c}1.8 \\
\pm 0.05\end{array}$ & $\begin{array}{c}0.8 \downarrow^{*} \\
\pm 0.032\end{array}$ \\
\hline
\end{tabular}

Number of rats in control groups $=6$

Number of rats in treated group $=8$

$* \mathrm{P}<0.05$

$* * \mathrm{P}<0.01$

\section{Legend of figures}

Fig.1 : Control rat liver showing the normal histological structure $\mathrm{H} \& \mathrm{E} \times 200$

Fig.2: Liver of rat treated with $(1.3 \mathrm{~g} / \mathrm{k})$ aqueous extract of P.granatum for month showing severe congestion of central vein , dilatation of sinusoids and vacuolization of hepatocytes and Inflammatory cells were detected inbetween hepatocytes $\mathrm{H} \& \mathrm{E} \times 400$ Fig.3:Liver of rat treated with $(1.3 \mathrm{~g} / \mathrm{k})$ aqueous extract of P.granatum for month vacuolization and ballooning also a lot of pyknotic nuclei were detected with many necrotic areas of hepatocytes. $\mathrm{H} \& \mathrm{E}$ $\mathrm{x} 400$

Fig.4: Liver of rat treated with $(1.3 \mathrm{~g} / \mathrm{k})$ aqueous extract of P.granatum for month showing dilatation of portal tract and fibrosis around it $\mathrm{H} \& \mathrm{E} \times 250$
Fig.4a: Liver of rat treated with $(1.3 \mathrm{~g} / \mathrm{k})$ aqueous extract of $\mathrm{P}$. granatum for month showing dilatation of portal tract and fibrosis was noticed around it, dilated endothelium with the disappearance of their nuclei,debris of a lot of hepatocytes were observed (d), a large necrotic area could be detected(n) H\&E x 500

Fig.5: kidney of control rat $\mathrm{H} \& \mathrm{E}$ x 250 Fig.6: kidney of of rat treated with $(1.3 \mathrm{~g} / \mathrm{k})$ aqueous extract of $\mathrm{P}$. granatum for month showing glomeruli were congested and compact H\&E x 500

Fig.7 : kidney of rat treated with $(1.3 \mathrm{~g} / \mathrm{k})$ aqueous extract of $\mathrm{P}$. granatum for month showing swelling of glomeruli and degenerated tubules $\mathrm{H} \& \mathrm{E} \times 400$

Fig.8 : kidney of of rat treated with $(1.3 \mathrm{~g} / \mathrm{k})$ aqueous extract of $\mathrm{P}$. granatum for month 
showing dilatation and severe congestion of blood vessels,

Fig.9 :some nuclei of convoluted tubules appeared faintly stained and their cells appeared moderately affected, some glomeruli appeared lobulated and atrophied $\mathrm{H} \& \mathrm{E} \times 250$

kidney of of rat treated with $(1.3 \mathrm{~g} / \mathrm{k})$ aqueous extract of $\mathrm{P}$. granatum for month showing degenerated glomerulus $H \& E x 250$

Fig.10: kidney of rat treated with $(1.3 \mathrm{~g} / \mathrm{k})$ aqueous extract of $\mathrm{P}$. granatum for month showing diffuse extravagations of red blood cells between the degenerated renal tubules $\mathrm{H} \& \mathrm{E} \times 500$

Fig.11: Aorta of control rat $H \& E \times 250$

Fig.13: Aorta of rat treated with $(1.3 \mathrm{~g} / \mathrm{k})$ aqueous extract of $\mathrm{P}$. granatum for month showing formation of medial calcinosis in aorta with irregularity of tunica intima $\mathrm{H} \& \mathrm{E} \times 100$

Fig.13a: Aorta of rat treated with $(1.3 \mathrm{~g} / \mathrm{k})$ aqueous extract of $\mathrm{P}$. granatum for month showing formation of medial calcinosis in aorta with irregularity of tunica intima $\mathrm{H} \& \mathrm{E} \times 160$

Fig.14:Testis of control rat H\&E x 200

Fig.15: Testis of rat treated with $(1.3 \mathrm{~g} / \mathrm{k})$ aqueous extract of $\mathrm{P}$. granatum for month showing some tubules appeared normal and others contained less spermatogenic activity with reduction in sperm number and leyding cells H\&Ex250

Fig.15a: Testis of rat treated with $(1.3 \mathrm{~g} / \mathrm{k})$ aqueous extract of $\mathrm{P}$. granatum for month showing some tubules appeared normal and others appeared moderately affected $\mathrm{H} \& \mathrm{Ex} 500$
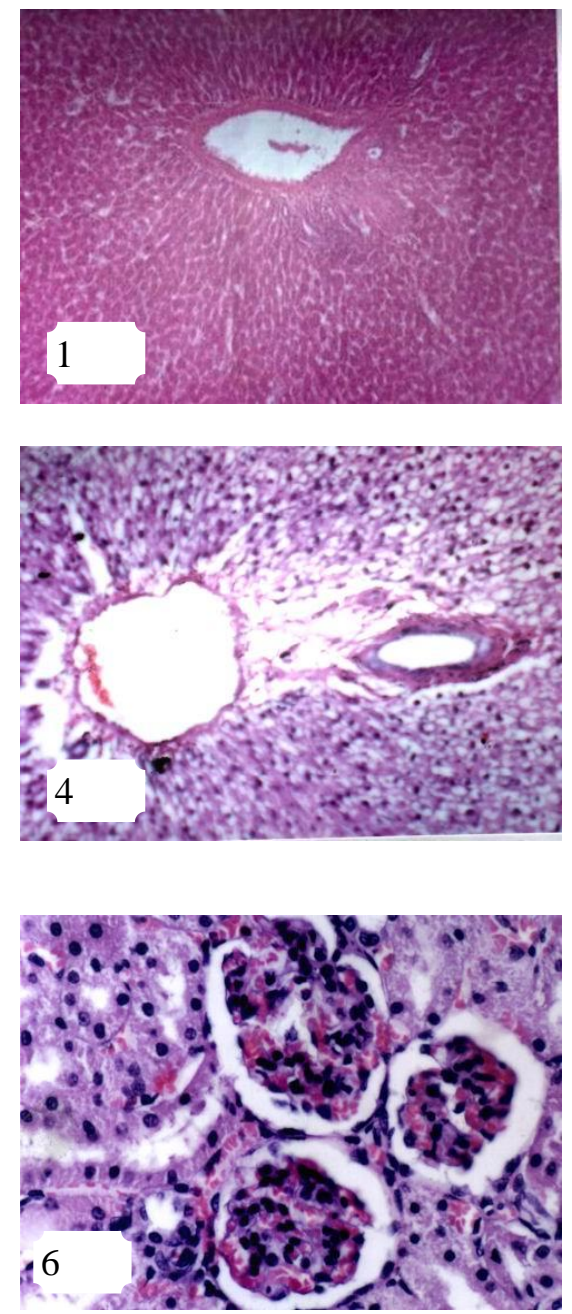
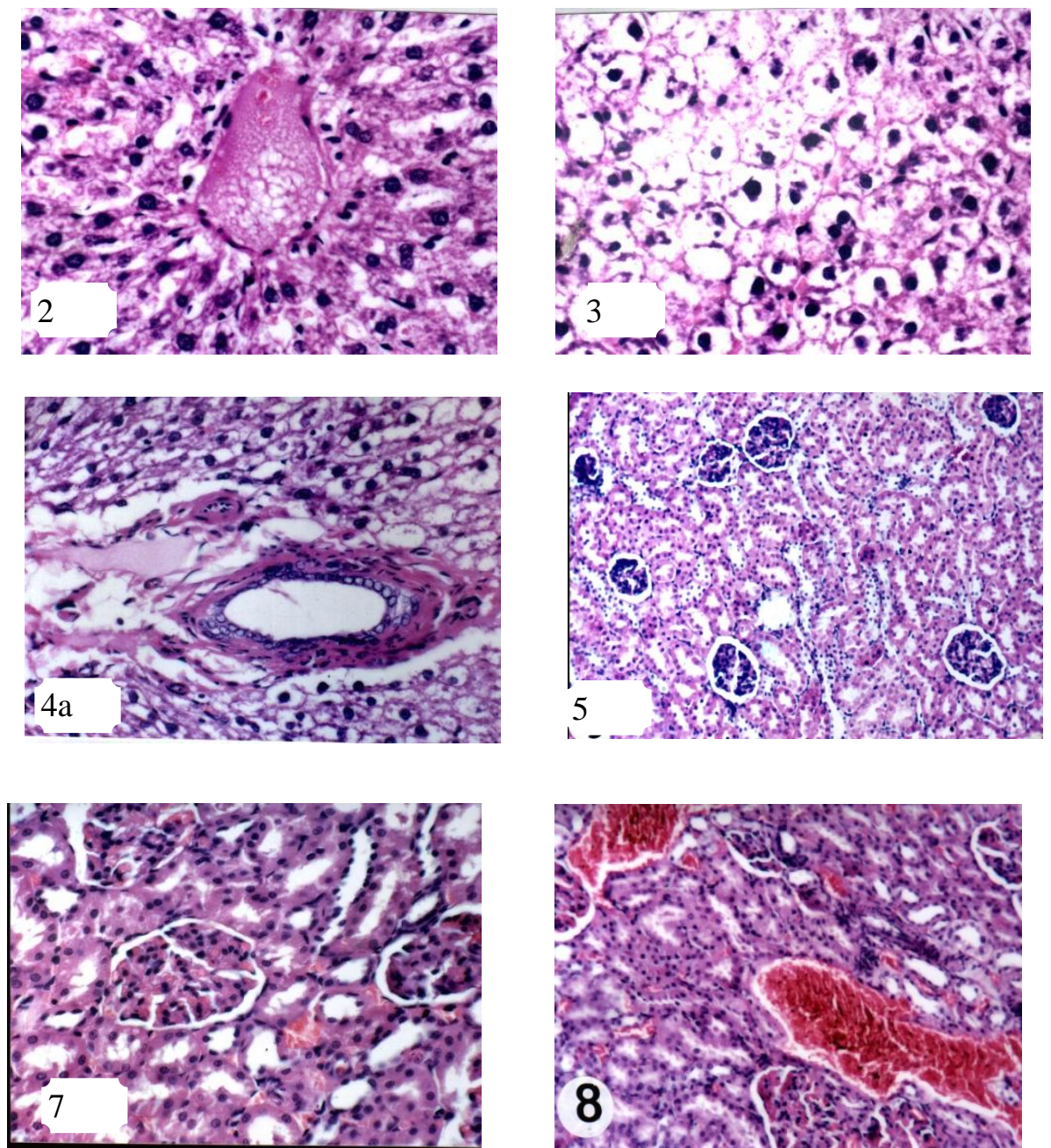

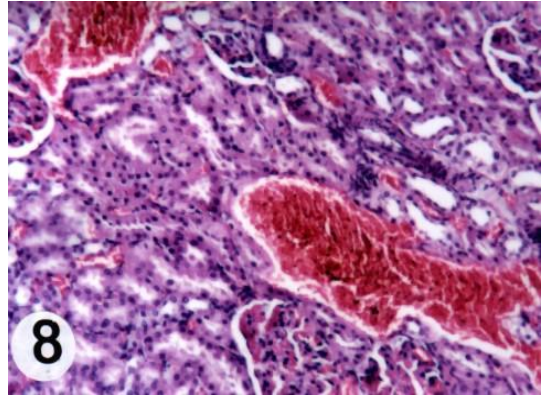



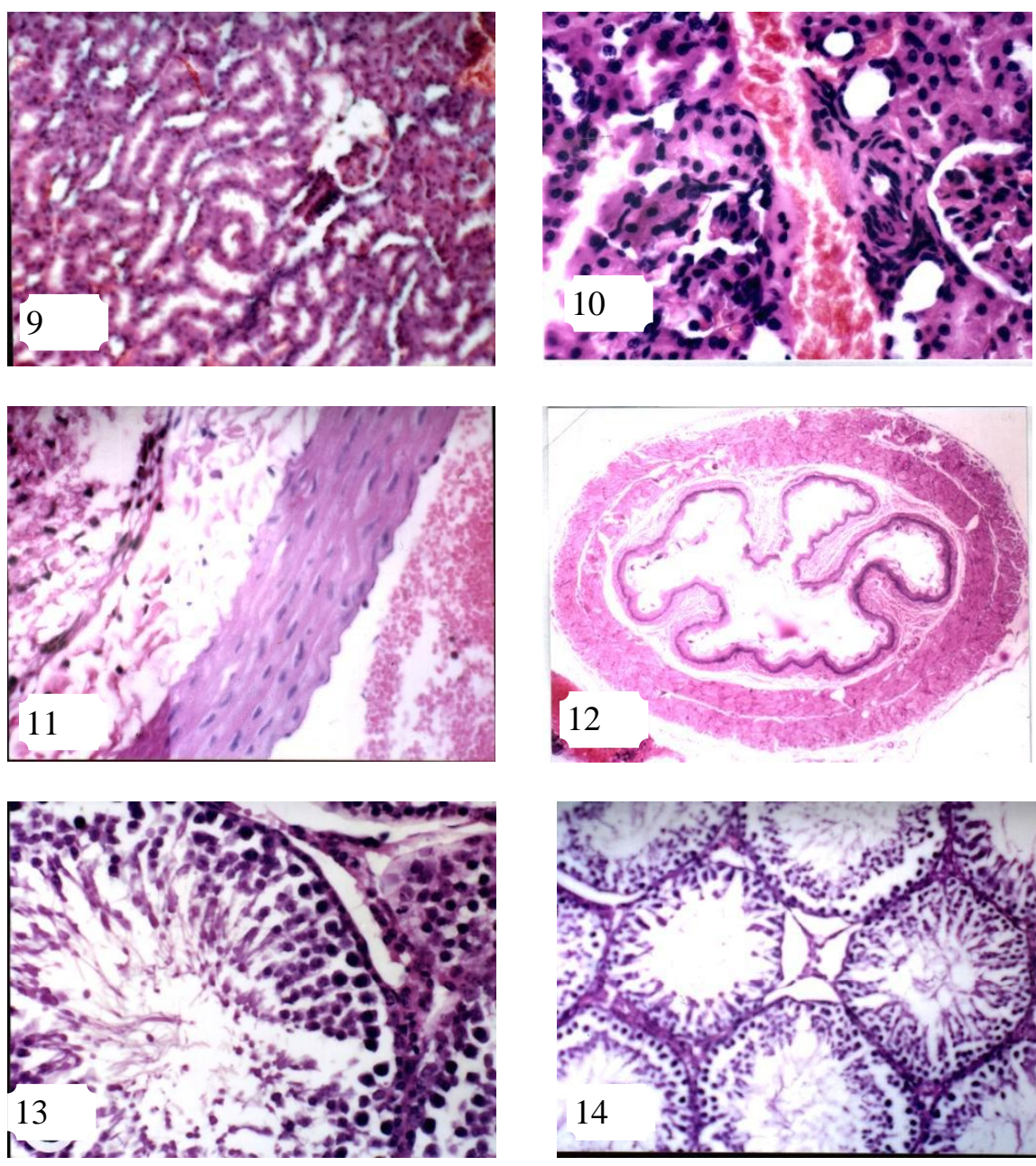
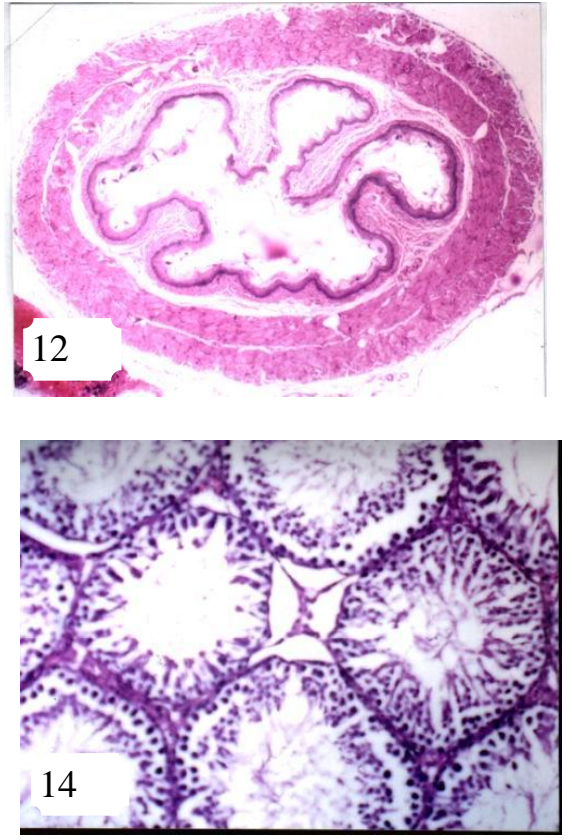
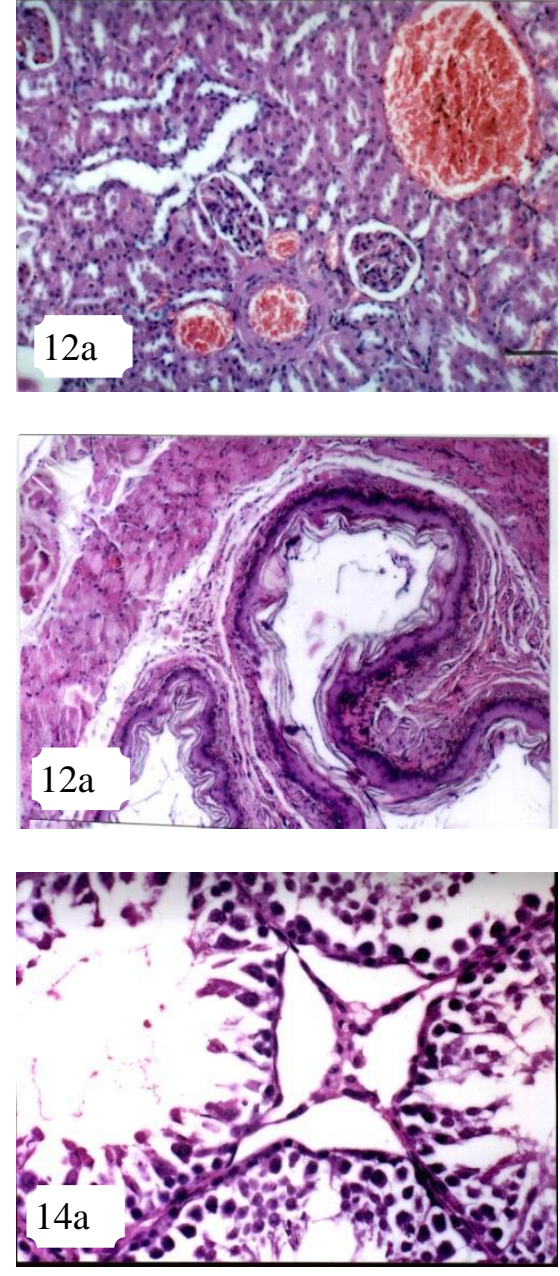

\section{References}

1. Afaq, F. ; Saleem, M. ;Krueger, C.G.; Reed, J.D. and Mukhtar H. (2004): Anthocyanin-and hydrolysable tannin- rich pomegranate fruit extract modulates MAPK and NF-kappa B pathways and inhibits skin tumorigenesis in CD-1mice.Int.J.Cancer.28

2. 2-Allain,C.C.; Poon,L.S.; Chem,C.S.; , Richamond, W. and Fu,P.C.(1974): Enzymatic determination of total serum cholesterol .Clin ,Chem,20,4.

3. Aviram, M.; Rosenblat,M.; Gaitini ,D.; Nitecki S.; Hoffman A.; Dornfeld L.; Volkova N.;Presser D.; Attias J. Liker,H. and Hayek T.(2004): Pomegranate juice consumption for three years by patients With carotid artery stenosis ereduces common carotid intima -media thickness, blood pressure and LdL oxidation. Clin. Nutr.; 23 (3):423

4. Bartles, H.; Bohmer, M.; Filler G.,Priem F and Lepage,N. (1971): Micro-determination of creatinine. Clin Chem Acta 32,81.

5. Ben-Nasr, C.; Ayed, N.; and Metche, $M$ (1996): Quantitative determination of the polyphenolic content of pomegranate peel. Z.Lebensm.unters .Forsch ;203(4) :374

6. Bucolo, G. and David, H.(1973): Quantitative determination of serum trigly-cerides by the use of enzymes .Clin, Chem., 19,476.

7. Carraz, G.L.M. ;Willemot, J. and Demenge,P. (1978): Penta-O-gal-loyl-ßglucose is useful as an hypoglycaemic agent. Fr. Demande2, 380,29

8. Chidambara,M. K. ;Reddy ,V.K.; Veigas, J. M. and Murthy,U.D. (2004): Study on wound healing activity of Punica granatum peel .J. Med.;7(2):256

9. Das, A.K.; Mandal,S.C.; Banerjee, S.K.;Sinha,s.;Das,J.Saha,B.and Pal,M. (1999): Studies on anti diarrhoeal activity of Punica granatum seed extract in rats.J.Ethnopharmacol ;15;68(1-3):205

10. Das, A.K.; Mandal,S.C.; Banerjee, S.K.;Sinha,s.; Saha,B. Pal,M.(2001): Studies on the hypoglycaemic of Punica granatum seed in streptozotocin induced diabetic rats. Phytother. Res.15,628 
11. Duck,J.A.; Codwin, M.J.,and Cillier, J.(2002): Hand Book of Medicinal Herbs CRC press P.582

12. German Society for clinical chemistry (1972): Standard method for clinical chemistry, standard method for determination of alkaline phosphatase (ALP) activity. J.Clin. Chem. Clin. Biochem. 290

13. Jafri, M.A.; Aslam, M. ;Javed ,K. Singh, S.(2000):Effect on Punica granatum linn. (flowers) on blood glucose level in normal and alloxan -induced diabetic rats.J.Ethonpharma.70,309

14. Kaneto, M.; Kanamor, I. S. Hishikawa, A. and Kishi, K.(1999): Epididymal sperm motion as a parameter of male reproductive toxicity :sperm motion ,fertility and histopathology in ethynyle estradiol treated rats .Reprod. Toxicol;(4):279

15. Kawaii,S.and Lansky E.P.(2004): Differentiation -promoting activity of pomegranate (Punicagranatum)fruit extracts in Hl-60 humanpromyelocytic leukemia cells.J.Med.Food 7(1):13

16. Kummer,v.;Maskova,J.;Canderle,j;Zral y,Z.andNEca,J.(2001): Estrogenic effects of silymarin in ovariectomized rats.Vet.Med.Czech.46,17

17. Lanter,A.L.(1975):Clinical Biochemistry , $7^{\text {th }}$ ed $.1^{\text {st }}-6^{\text {th }}$ ed by A.Cantarow and M. Trumper. W. B. Saunders Company p.618.

18. Mori-Okamoto,J.; Otawara- Hamamoto ,Y. ;Yamato,H. and Yoshimura $H$. (2004): Pomegranate extract improves a depressive state and bone properties in menopausal syndrome model ovariectomized mice.J. Ethnopharmacol.; 92(1):93

19. Noda, Y.; Kaneyuki, T.; Mori A. and Packer,L.(2002): Antioxidant activities of pomegranate fruit extract and its anthocyanidins: delphinidin, cyaniding, and pelargonidin.J.Agri. Food Chem.2;50(1): 166.

20. Nozire ,O. and Serpil,D.(1993): Valuation of the pomegranate (Punica granatumL.) peels from the stand point of pharmacy .Ankara Ecz.Fak.Derg.,22(1-2): 21

21. Paget, G. E. and Barnes, J.M.(1964):"In toxicity tests" Vol.(1). Chapter (6) P.135, Editor Laurance, D.R. and A. L. Academic Press, London, New York

22. Pederson,M., (1998): Nutritional Herbology a Reference Guide to Health $4^{\text {th }}$ printing Printing, revised and expanded edition ,Wendell W. Whiteman Co., Warsdaw,I.N.

23. Peirce,A.,(1999): The AphA Practical Guide to natural Medicines , Stonesong
Press ,Wm. Morrow \&Co., Inc., New York Book

24. Reitman ,S. and Frankle,S.(1957) : A colorimetric method for determination of serum glutamic oxaloacetic and glutamic pyruvic transaminases .Am. J. Clin Path.28:56

25. Sastravaha,G. Yotnuengnit, p. Booncong P.and Sangtherapitikul P. (2003): Adjunctive periodontal treatment with Centella asiatica and Punica granatum extracts. preliminary study. J.Int.Acad Periodontol;5(4):106

26. Satomi,H.; Umemura,K.;Ueno,A.Hatano ,T.Okuda,T.Noro,T.(1993):Carbonic anhydrrase inhibtors from the pericarps of Punica granatum L.Biol.Pharm.Bull.; 16(8):787.

27. Satyavati, G. V. ;Gupta, A. K. and Tandon, N.(1978): Medicinal Plants of India,Vol.2.Indian Council of Medicinal Research,New Delhi,P.539

28. Schubert ,S.Y., Lansky,E.P. and Neeman ,I.(1999): Antioxidant and eicosanoid enzyme inhibition propertiesof pomegranate seed oil and fermented juice flavonoids.J.Ethnopharmacol;66(1):11.

29. Sendecor, G.W. and Coebram, W.C., 1969): In "statistical Methods " $6^{\text {th }}$ ed Iowa State Univ. Press Anes, Iowa, U. S.A. P.70

30. Singhal,K.C.(1983): Anthlmintic activity of Punica granatum and Artemesia siersiana against experimental infection in mice .Ind.J.Pharmacol.15,119

31. Tabacco,A.;Meiattini,F.;Moda,E. and Tarli P.(1979): Simplified enzymatic /colorimetric serum urea nitrogen determination .Clin. Chem.Feb.25,(2):336.

32. Van-Elswijk,D.A., Schobel, U.P. Lansky, E.p. Irth ,H.and Van- der- Greef ,G.(2004):Rapid dereplication of estrogen compounds in Punica granatum using online biochemical detection coupled to mass spectrometry Phytochemistry;65(2):233

33. Vasconcelos ,L.C.,Sampaio M.C. Sampaio F.C.and HiginoJ.S.(2003): Use of punica granatum as an anti fungal agent against candidosis associated with denture stomatitis. Mycoses;46(5-6);192.

34. Vidal,A.;Fallarero,A;Pena,B.;Medima,M .Gra,B.River,F.;Gutierrez,Y.andVuorela, M.(2003):Studies on the toxicity of Punica granatum L.(punicaceae) whole fruit extracts.J.Ethnopharma,89(2-3).295.

35. Weber, K.; Setchell, K.; and Lephart,E. (2001): Dietary soy -phytoestrogens decrease Testosterone levels and prostate weight without altering LH,prostate 
Enas A. M. Khalil

$5 \alpha$ reductase or testicular steroidogenic acute regulatory peptide levels in adult

sprague- Dawly rats.J.Endocrinnol.,170 (3), 591

دراسات كييائبه حيويه وهستوباثوليوجيه على التغيرات الحادثه فح ذكور

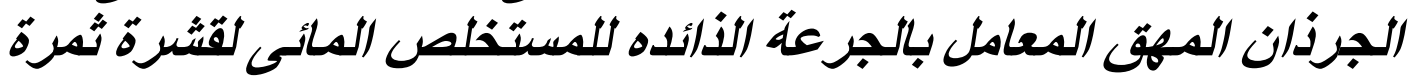

$$
\text { الرمان }
$$

إيناس على مهدى خليل

الهيئة القوميه للرقابه و البحوث الدو فئيه

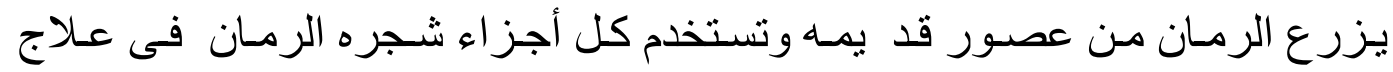

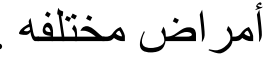

ويهدف البحث الى دراسة نأثير الجرعه الذائده للمستخلص المائى لقشرة الرمان لمدة شهر

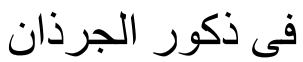
و أظهرت المعرد الجرذانه بألجر عه 1,3جم /كم من الستخلص المائى لقشـرة الرمـان لمدة شـهر فى في

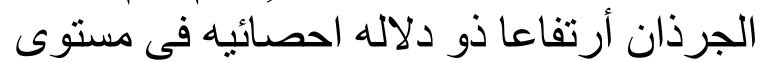

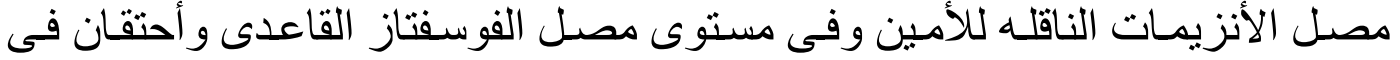

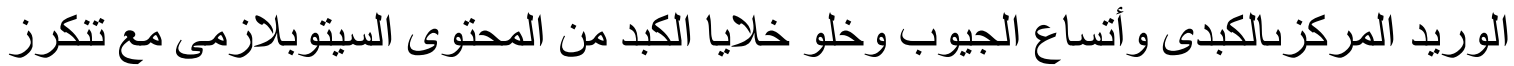

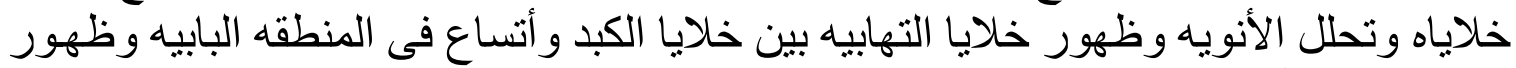

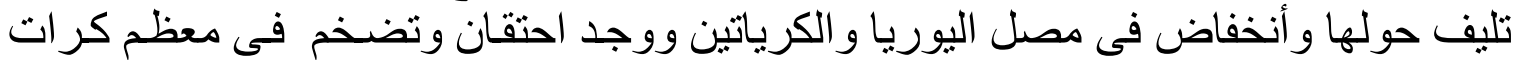

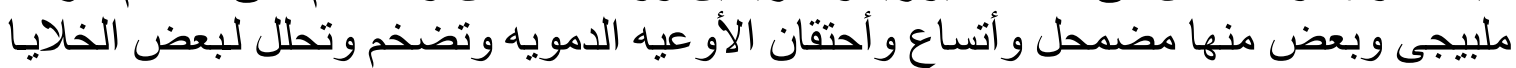

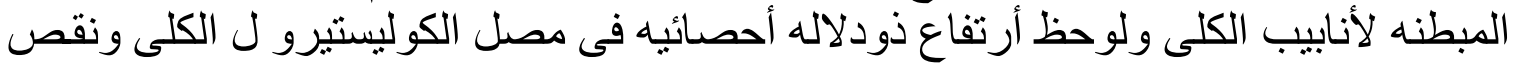

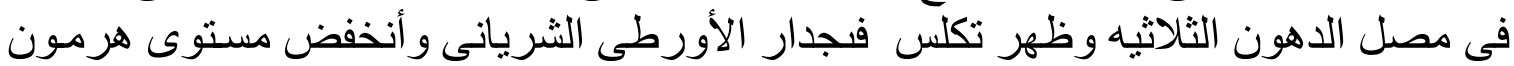
التيستيرون وموت كثير من الحيو النات التيه المنويه

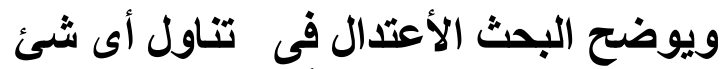

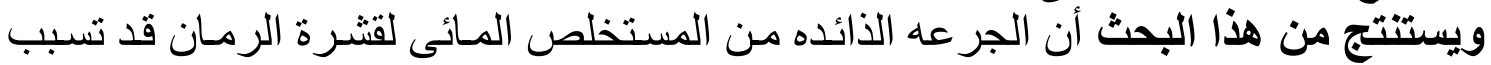

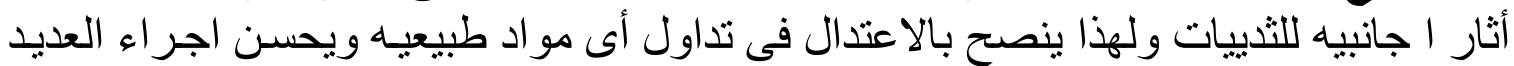

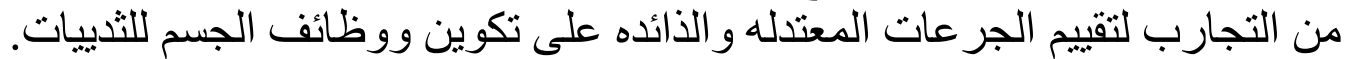

